\title{
Outcomes in rheumatoid arthritis patients treated with abatacept: a UK multi-centre observational study
}

Ernest Choy ${ }^{1,2}$, Lara Groves ${ }^{3}$, Daniel Sugrue ${ }^{3}$, Michael Hurst ${ }^{3}$, John Houghton ${ }^{3}$, Srinivasan Venkatachalam4, Yusuf I. Patel ${ }^{5}$, James R. Maxwell ${ }^{6}$, Kevin G. Pollock ${ }^{7}$ and Sadie Henning ${ }^{7^{*}}$

\begin{abstract}
Background: Rheumatoid arthritis (RA) is an inflammatory autoimmune disease that causes chronic synovitis, resulting in progressive joint destruction and functional disability and affects approximately 400,000 people in the UK. This real-world study aimed to describe the characteristics, treatment patterns and clinical outcomes of patients who received abatacept in UK clinical practice.

Methods: This was a multi-centre, retrospective, observational study of patients with RA treated with abatacept at four UK centres between 01 January 2013 and 31 December 2017. Data were collected from medical records of each patient from the index date (date of first bDMARD initiation) until the most recent visit, death or end of study (31 December 2017).

Results: In total, 213 patients were included in the study. Patients received up to eight lines of therapy (LOTs). Treatment with abatacept, or any other bDMARD, was associated with reductions in DAS28-ESR and DAS28-CRP scores at 6 and 12 months. The distribution of EULAR responses (good/moderate/no response) tended to be more favourable for patients when receiving abatacept than when receiving other bDMARDs (22.8\%/41.3\%/35.9\% versus $16.6 \% / 41.4 \% / 42.1 \%$ at 6 months, and $27.9 \% / 36.1 \% / 36.1 \%$ versus $21.2 \% / 34.5 \% / 44.2 \%$ at 12 months). Patients receiving abatacept at LOT1 $(n=68)$ spent significantly longer on treatment compared with patients receiving other bDMARDs (53.4 vs. 17.4 months; $p<0.01$ ); a similar trend was observed for LOT2. Among patients who discontinued after 6 months, a greater proportion experienced infection requiring antibiotics when receiving other bDMARDs compared to those receiving abatacept.
\end{abstract}

Conclusions: RA patients who received bDMARDs, including abatacept, experienced reduced disease activity. When receiving abatacept as first or second line of therapy, patients persisted with treatment significantly longer than those receiving other bDMARDs.

Keywords: Abatacept, Biologic, DMARD, Disease activity, Observational study, Rheumatoid arthritis, Time on treatment

\footnotetext{
* Correspondence: sadie.henning@bms.com

${ }^{7}$ Bristol Myers Squibb, Uxbridge Business Park, Sanderson Road, Uxbridge,

Middlesex, UK

Full list of author information is available at the end of the article
}

C The Author(s). 2021 Open Access This article is licensed under a Creative Commons Attribution 4.0 International License, which permits use, sharing, adaptation, distribution and reproduction in any medium or format, as long as you give appropriate credit to the original author(s) and the source, provide a link to the Creative Commons licence, and indicate if changes were made. The images or other third party material in this article are included in the article's Creative Commons licence, unless indicated otherwise in a credit line to the material. If material is not included in the article's Creative Commons licence and your intended use is not permitted by statutory regulation or exceeds the permitted use, you will need to obtain permission directly from the copyright holder. To view a copy of this licence, visit http://creativecommons.org/licenses/by/4.0/ The Creative Commons Public Domain Dedication waiver (http://creativecommons.org/publicdomain/zero/1.0/) applies to the data made available in this article, unless otherwise stated in a credit line to the data. 


\section{Background}

Rheumatoid arthritis (RA) is a systemic autoimmune disease driven by both pro-inflammatory cytokines and pathogenic autoantibodies that causes chronic synovitis, resulting in progressive joint destruction and functional disability [1-5]. RA-driven inflammatory processes are also associated with interstitial lung disease and cardiovascular disease, leading to increased disability and mortality [1]. It is estimated that over 400,000 people in the UK have RA [6, 7], and this progressive and often debilitating disease can have a detrimental effect on quality of life for patients, their families, and carers $[8,9]$.

Whilst there is no cure for RA, current therapies aim to slow disease progression by reducing inflammation and minimising joint damage. National and international treatment guidelines recommend treatment with biological DMARDs (bDMARDs), such as abatacept, after failure of conventional synthetic disease-modifying antirheumatic drugs (csDMARDs) when the treatment target is not achieved or poor prognostic factors are present [10-12]. Positivity for rheumatoid factor (RF) and/or anti-citrullinated protein-peptide antibodies (ACPA) is a useful diagnostic and prognostic marker for RA as they may affect treatment response, with some evidence that the presence of these autoantibodies is associated with poorer outcomes [13-18].

International observational studies demonstrate the impact of abatacept on patient outcomes [19], as well as prognostic factors for abatacept retention [20] and durability [21, 22]. Others have found that abatacept performs favourably in terms of treatment persistence when compared to tumour necrosis factor inhibitors (TNFi) [23] and other non-TNFi [24]. However, clinical effectiveness and treatment patterns of abatacept for treating RA have not been well-studied in real-world routine practice, notably in a UK population. Therefore, this study aimed to investigate the characteristics of patients who received abatacept in the UK real-world setting, their treatment patterns and disease activity.

\section{Methods}

This study was a multi-centre, retrospective, observational chart review of patients with RA treated with abatacept at four UK centres: University Hospital of Wales, The Royal Wolverhampton NHS Trust, Hull University Teaching Hospitals NHS Trust, Sheffield Teaching Hospitals NHS Foundation Trust. The research window was from 01 January 2013 to 31 December 2017. The index date was defined as the date of first bDMARD initiation (irrespective of line of therapy (LOT)). Data were collected for each patient until the most recent visit (up until 31 December 2017) or death.

The study received ethical approval form the Yorkshire \& The Humber - South Yorkshire Research Ethics
Committee (Reference: 18/YH/0412) and research permissions from the Health Research Authority (Reference: 242712).

Eligible patients were identified through screening of medical records at the study centres. Patients were included in the study if they met all the following criteria: aged $\geq 18$ years on index date (date of first bDMARD initiation); received abatacept for the treatment of RA at any LOT within the research window (01 January 2013 to 31 December 2017); medical records contained at least two of disease activity score for 28 joints - erythrocyte sedimentation rate (DAS28-ESR) or disease activity score for 28 joints - C-reactive protein (DAS28-CRP) scores as part of RA treatment monitoring: one on index date and another score at $6 \pm 3$ months and/or $12 \pm 3$ months following treatment initiation. Patients with preclinical RA, including undifferentiated arthritis, and/or with comorbid RA or other types of (non-rheumatoid) arthritis were excluded from the study.

A bespoke electronic case report form (eCRF) was used to record all study data. Data from each eligible patient were extracted from medical records and entered into the eCRF by the investigator or their assigned staff at each study centre. The eCRF allowed investigators to remove patient identifiers and ensure only pseudoanonymised patient-level data were analysed. Built-in validation checks were also used to facilitate accurate and valid data entry. Data collection was entirely retrospective and did not involve any direct patient contact.

Baseline patient demographic and clinical characteristics were analysed descriptively, where baseline was defined as the index date (date of first bDMARD initiation). Summary statistics (mean, standard deviation, median and interquartile range $[\mathrm{IQR}]$ ) were presented for continuous variables, with counts, proportions, and percentages presented for categorical variables. Analyses were also stratified by positive and/or negative ACPA and RF status. Time on treatment was summarised as a continuous variable and time-toevent curves (based on time to treatment discontinuation or end of follow up [EOFU]) were derived using the Kaplan-Meier method. Log-rank and Wilcoxon tests were used to ascertain statistically significant differences in time on treatment between subgroups. Changes in DAS28 scores were calculated from LOT initiation: 6 month scores were calculated using the recorded score closest to the end of month 6 and included scores recorded between months 4 and 9; 12 months scores were calculated using the recorded score closest to the end of month 12 and included those recorded between months 10 and 15. Associations between change in DAS28 (ESR or CRP) score and bDMARD were modelled using a linear mixedeffects model. 
Table 1 Patient demographics, clinical characteristics and disease activity scores at baseline

\begin{tabular}{|c|c|c|c|c|c|c|}
\hline \multirow[t]{2}{*}{ Variable } & \multirow{2}{*}{$\begin{array}{l}\text { All patients } \\
(n=213)\end{array}$} & \multicolumn{5}{|c|}{ By ACPA/RF status } \\
\hline & & $\begin{array}{l}\mathrm{ACPA}+/ \mathrm{RF}+(n \\
=76)\end{array}$ & $\begin{array}{l}\text { ACPA+ /RF- }(n \\
=7)\end{array}$ & $\begin{array}{l}\text { ACPA- /RF+ }(n \\
=10)\end{array}$ & $\begin{array}{l}\text { ACPA-/RF- }(n \\
=22)\end{array}$ & $\begin{array}{l}\text { ACPA and/or RF status not } \\
\text { recorded }(n=98)\end{array}$ \\
\hline \multicolumn{7}{|c|}{ Demographics (at index date unless specified) } \\
\hline \multicolumn{7}{|l|}{ Age (years old) } \\
\hline Mean (SD) & $55.2(13.1)$ & $56.1(12.9)$ & $46.2(6.6)$ & $54.6(13.3)$ & $54.0(15.2)$ & $55.5(13.1)$ \\
\hline Median (IQR) & $\begin{array}{l}55.4(46.9- \\
64.6)\end{array}$ & $56.2(48.3-64.1)$ & $47.8(43.9-48.8)$ & $51.4(45.1-63.5)$ & $57.5(43.6-67.0)$ & $55.1(48.0-64.7)$ \\
\hline \multicolumn{7}{|l|}{ Sex } \\
\hline Female, n (\%) & $152(71.4 \%)$ & $54(71.1 \%)$ & a & $10(100.0 \%)$ & $17(77.3 \%)$ & $66(67.3 \%)$ \\
\hline \multicolumn{7}{|l|}{ Weight (kg) } \\
\hline Mean (SD) & $79.4(17.8)$ & $79.7(18.7)$ & $80.1(12.6)$ & $78.7(16.0)$ & $90.2(23.0)$ & $77.3(16.1)$ \\
\hline Median (IQR) & $\begin{array}{l}77.2(65.8- \\
89.7)\end{array}$ & $76.2(65.6-95.0)$ & $79.4(70.1-89.4)$ & $71.9(68.8-84.9)$ & $86.2(75.0-91.0)$ & $76.8(64.9-88.3)$ \\
\hline \multicolumn{7}{|l|}{$\mathrm{SBP}(\mathrm{mmHg})$} \\
\hline Mean (SD) & $134.8(19.3)$ & $131.5(21.2)$ & $129.7(14.6)$ & $145.3(24.7)$ & $143.8(15.4)$ & $135.0(17.1)$ \\
\hline Median (IQR) & $\begin{array}{l}133.0(120.0- \\
146.5)\end{array}$ & $\begin{array}{l}129.0(114.5- \\
142.5)\end{array}$ & $\begin{array}{l}136.0(124.5- \\
138.0)\end{array}$ & $\begin{array}{l}144.0(124.8- \\
163.5)\end{array}$ & $\begin{array}{l}139.0(134.0- \\
158.5)\end{array}$ & $133.0(120.0-147.5)$ \\
\hline \multicolumn{7}{|l|}{$\mathrm{DBP}(\mathrm{mmHg})$} \\
\hline Mean (SD) & 78.7 (10.9) & $77.2(11.0)$ & $70.7(7.4)$ & $73.1(11.8)$ & $85.1(12.1)$ & $80.0(10.0)$ \\
\hline Median (IQR) & $\begin{array}{l}78.0(70.0- \\
86.0)\end{array}$ & $75.0(70.0-84.5)$ & $68.0(66.5-73.5)$ & $71.0(64.8-79.0)$ & 83.5 (77.3-91.5) & 79.5 (74.3-86.8) \\
\hline \multicolumn{7}{|l|}{ Smoking status } \\
\hline $\begin{array}{l}\text { Current smoker - } \\
\mathrm{n}(\%)\end{array}$ & 39 (18.3\%) & $14(18.4 \%)$ & $0(0.0 \%)$ & a & a & $21(21.4 \%)$ \\
\hline $\begin{array}{l}\text { Past smoker - n } \\
(\%)\end{array}$ & $26(12.2 \%)$ & 15 (19.7\%) & $0(0.0 \%)$ & a & a & 7 (7.1\%) \\
\hline $\begin{array}{l}\text { Never smoked - n } \\
(\%)\end{array}$ & $61(28.6 \%)$ & $20(26.3 \%)$ & a & a & $8(36.4 \%)$ & $25(25.5 \%)$ \\
\hline Unknown - n (\%) & $87(40.8 \%)$ & 27 (35.5\%) & a & a & 7 (31.8\%) & 45 (45.9\%) \\
\hline \multicolumn{7}{|l|}{ Year of RA diagnosis } \\
\hline$\leq 2009-\mathrm{n}(\%)$ & 39 (18.3\%) & a & a & a & a & $18(18.4 \%)$ \\
\hline $2010-\mathrm{n}(\%)$ & $45(21.1 \%)$ & $16(21.1 \%)$ & a & a & a & $22(22.4 \%)$ \\
\hline 2011 - n (\%) & $66(31.0 \%)$ & $17(22.4 \%)$ & a & a & $6(27.3 \%)$ & 39 (39.8\%) \\
\hline 2012 - n (\%) & $54(25.4 \%)$ & $26(34.2 \%)$ & a & a & $9(40.9 \%)$ & a \\
\hline 2013 - n (\%) & $9(4.2 \%)$ & a & $0(0.0 \%)$ & a & $0(0.0 \%)$ & a \\
\hline \multicolumn{7}{|c|}{ RA duration at index date } \\
\hline Mean (SD) & $7.0(7.9)$ & $6.4(8.1)$ & $8.7(8.1)$ & $5.4(6.5)$ & $5.7(5.4)$ & $7.7(8.2)$ \\
\hline Median (IQR) & $3.9(2.1-8.5)$ & $3.3(2.1-7.2)$ & $4.6(4.3-10.5)$ & $2.2(1.3-6.9)$ & $3.8(1.9-7.8)$ & $5.1(2.5-9.0)$ \\
\hline \multicolumn{7}{|c|}{ Patient history ( 5 years prior to index date), $\mathrm{n}(\%)$} \\
\hline $\begin{array}{l}\text { Myocardial } \\
\text { infarction }\end{array}$ & $8(3.8 \%)$ & a & $0(0.0 \%)$ & $0(0.0 \%)$ & $0(0.0 \%)$ & a \\
\hline $\begin{array}{l}\text { Other ischemic CV } \\
\text { disease }\end{array}$ & $11(5.2 \%)$ & a & $0(0.0 \%)$ & $0(0.0 \%)$ & a & $5(5.1 \%)$ \\
\hline Stroke & $5(2.3 \%)$ & a & $0(0.0 \%)$ & $0(0.0 \%)$ & a & a \\
\hline Cancer & $13(6.1 \%)$ & $6(7.9 \%)$ & $0(0.0 \%)$ & a & a & a \\
\hline COPD & $10(4.7 \%)$ & a & $0(0.0 \%)$ & $0(0.0 \%)$ & a & $6(6.1 \%)$ \\
\hline Hypertension & 44 (20.7\%) & $14(18.4 \%)$ & a & a & $5(22.7 \%)$ & 20 (20.4\%) \\
\hline Asthma & $30(14.1 \%)$ & $11(14.5 \%)$ & a & a & $5(22.7 \%)$ & $9(9.2 \%)$ \\
\hline
\end{tabular}


Table 1 Patient demographics, clinical characteristics and disease activity scores at baseline (Continued)

\begin{tabular}{|c|c|c|c|c|c|c|}
\hline \multirow[t]{2}{*}{ Variable } & \multirow{2}{*}{$\begin{array}{l}\text { All patients } \\
(n=213)\end{array}$} & \multicolumn{5}{|c|}{ By ACPA/RF status } \\
\hline & & $\begin{array}{l}\text { ACPA+/RF+ }(n \\
=76)\end{array}$ & $\begin{array}{l}\text { ACPA+ /RF- ( } n \\
=7)\end{array}$ & $\begin{array}{l}\text { ACPA- /RF+ }(n \\
=10)\end{array}$ & $\begin{array}{l}\text { ACPA-/RF- }(n \\
=22)\end{array}$ & $\begin{array}{l}\text { ACPA and/or RF status not } \\
\text { recorded }(n=98)\end{array}$ \\
\hline $\begin{array}{l}\text { Interstitial lung } \\
\text { disease }\end{array}$ & $13(6.1 \%)$ & $7(9.2 \%)$ & $a$ & $0(0.0 \%)$ & $\mathrm{a}$ & $\mathrm{a}$ \\
\hline Diabetes & 15 (7.0\%) & $8(10.5 \%)$ & $0(0.0 \%)$ & $0(0.0 \%)$ & a & a \\
\hline \multicolumn{7}{|l|}{ ACPA titre $(\mathrm{U} / \mathrm{ml})$} \\
\hline$n$ & 119 & 76 & a & 10 & 22 & a \\
\hline Median (IQR) & $\begin{array}{l}100.0(8.2- \\
600.0)\end{array}$ & $\begin{array}{l}340.0(100.0- \\
600.0)\end{array}$ & $\begin{array}{l}100.0(100.0- \\
300.5)\end{array}$ & $2.2(0.3-5.3)$ & $0.0(0.0-1.0)$ & $51.0(30.9-123.0)$ \\
\hline \multicolumn{7}{|l|}{ RF titre (U/ml) } \\
\hline $\mathrm{n}$ & 180 & 76 & 7 & 10 & 22 & 65 \\
\hline Median (IQR) & $\begin{array}{l}61.0(16.9- \\
100.0)\end{array}$ & $\begin{array}{l}99.5(52.3- \\
100.0)\end{array}$ & $0.0(0.0-11.6)$ & $32.9(21.8-90.8)$ & $0.0(0.0-6.8)$ & $66.0(27.0-100.0)$ \\
\hline \multicolumn{7}{|l|}{ DAS28-ESR score } \\
\hline Mean (SD) & $6.3(1.0)$ & $6.3(0.9)$ & $6.9(0.9)$ & $6.0(0.9)$ & $6.4(0.8)$ & $6.2(1.2)$ \\
\hline Median (IQR) & $6.3(5.7-7.0)$ & $6.4(5.7-7.0)$ & $6.7(6.1-7.4)$ & $5.4(5.4-7.0)$ & $6.3(6.0-6.9)$ & $6.2(5.4-6.7)$ \\
\hline High - n (\%) & 89 (80.9\%) & $41(80.4 \%)$ & 7 (100.0\%) & a & $17(94.4 \%)$ & $22(75.9 \%)$ \\
\hline Moderate - n (\%) & $20(18.2 \%)$ & $10(19.6 \%)$ & $0(0.0 \%)$ & a & a & $6(20.7 \%)$ \\
\hline Low - n (\%) & a & $0(0.0 \%)$ & $0(0.0 \%)$ & $0(0.0 \%)$ & $0(0.0 \%)$ & a \\
\hline Remission - n (\%) & $0(0.0 \%)$ & $0(0.0 \%)$ & $0(0.0 \%)$ & $0(0.0 \%)$ & $0(0.0 \%)$ & $0(0.0 \%)$ \\
\hline \multicolumn{7}{|l|}{ DAS28-CRP score } \\
\hline Mean (SD) & $5.5(1.2)$ & $5.8(0.8)$ & $6.4(1.0)$ & $5.3(1.3)$ & $6.0(0.9)$ & $5.2(1.3)$ \\
\hline Median (IQR) & $5.5(4.8-6.3)$ & $5.7(5.2-6.3)$ & $6.0(5.8-6.6)$ & $5.5(4.5-6.1)$ & $6.1(5.5-6.7)$ & $5.1(4.3-6.3)$ \\
\hline High - n (\%) & $70(51.9 \%)$ & $27(60.0 \%)$ & a & $a$ & 7 (70.0\%) & $29(41.4 \%)$ \\
\hline Moderate - n (\%) & $60(44.4 \%)$ & $18(40.0 \%)$ & $0(0.0 \%)$ & a & a & $36(51.4 \%)$ \\
\hline Low - n (\%) & $a$ & $0(0.0 \%)$ & $0(0.0 \%)$ & $0(0.0 \%)$ & $0(0.0 \%)$ & a \\
\hline Remission - n (\%) & a & $0(0.0 \%)$ & $0(0.0 \%)$ & $0(0.0 \%)$ & $0(0.0 \%)$ & a \\
\hline
\end{tabular}

ACPA Anti-citrullinated protein antibodies, CV Cardiovascular, COPD Chronic obstructive pulmonary disease, CRP C-reactive protein, CV Cardiovascular, DAS28 Disease activity score, DBP Diastolic blood pressure, ESR Erythrocyte sedimentation rate, IQR Interquartile range, $R F$ Rheumatoid factor, SBP Systolic blood pressure, SD Standard deviation

${ }^{a}$ Cells suppressed due to small numbers

\section{Results}

In total, 213 patients met eligibility criteria and were included in the study. The mean age of patients was 55.2 years and $71.4 \%$ of patients were female. The majority of patients $(70.4 \%)$ were diagnosed with RA prior to 2009 and the median (IQR) RA disease duration was 3.9 (2.18.5) years (Table 1$)$. The study population contained: $\mathrm{ACPA}+/ \mathrm{RF}+, n=76$; $\mathrm{ACPA}+/ \mathrm{RF}-, n=7$; $\mathrm{ACPA}-/ \mathrm{RF}+n$ $=10$; ACPA-/RF-, $n=22$; unknown RF/ACPA status, $n=$ 98 (Table 1). Patients' demographic and clinical characteristics were also broadly comparable when stratified by LOT and treatment received.

Patients received up to 8 LOTs (Fig. 1). Patients who received abatacept in LOT1 usually did not receive any further lines of treatment $(n=63,92.6 \%)$. This was due to patients reaching EOFU ( $n=51,81.0 \%)$, adverse events $(n=5,7.9 \%)$, disease progression $(n=<5)$, or other reasons not otherwise stated $(n=5,7.9 \%)$. Patients receiving abatacept at LOT1 $(n=68)$ spent significantly longer on treatment compared with patients receiving other bDMARDs (median 53.4 vs. 17.4 months; $p<0.01$ ) (Fig. 2, Table 2). For patients receiving abatacept at LOT1, 85.6, 70.9 and $70.9 \%$ of patients were still in receipt of abatacept at 12, 24 and 36 months, respectively, compared with $63.4,39.3$ and $31.7 \%$ of patients receiving other bDMARDs, respectively. A similar pattern was observed at LOT2 $(n=59)$, with median time on treatment of 40.1 vs $17.1(p<0.01)$ months, respectively.

The number of patients who discontinued bDMARD treatment within 6 months and after 6 months of any LOT initiation, stratified by LOT, are summarised in Table 3. The proportion of patients receiving abatacept and still on treatment at EOFU was greater for all LOTs compared with patients who received other bDMARDs. Greater proportions of patients who discontinued other bDMARDs in LOTs 1-4 after 6 months tended to 


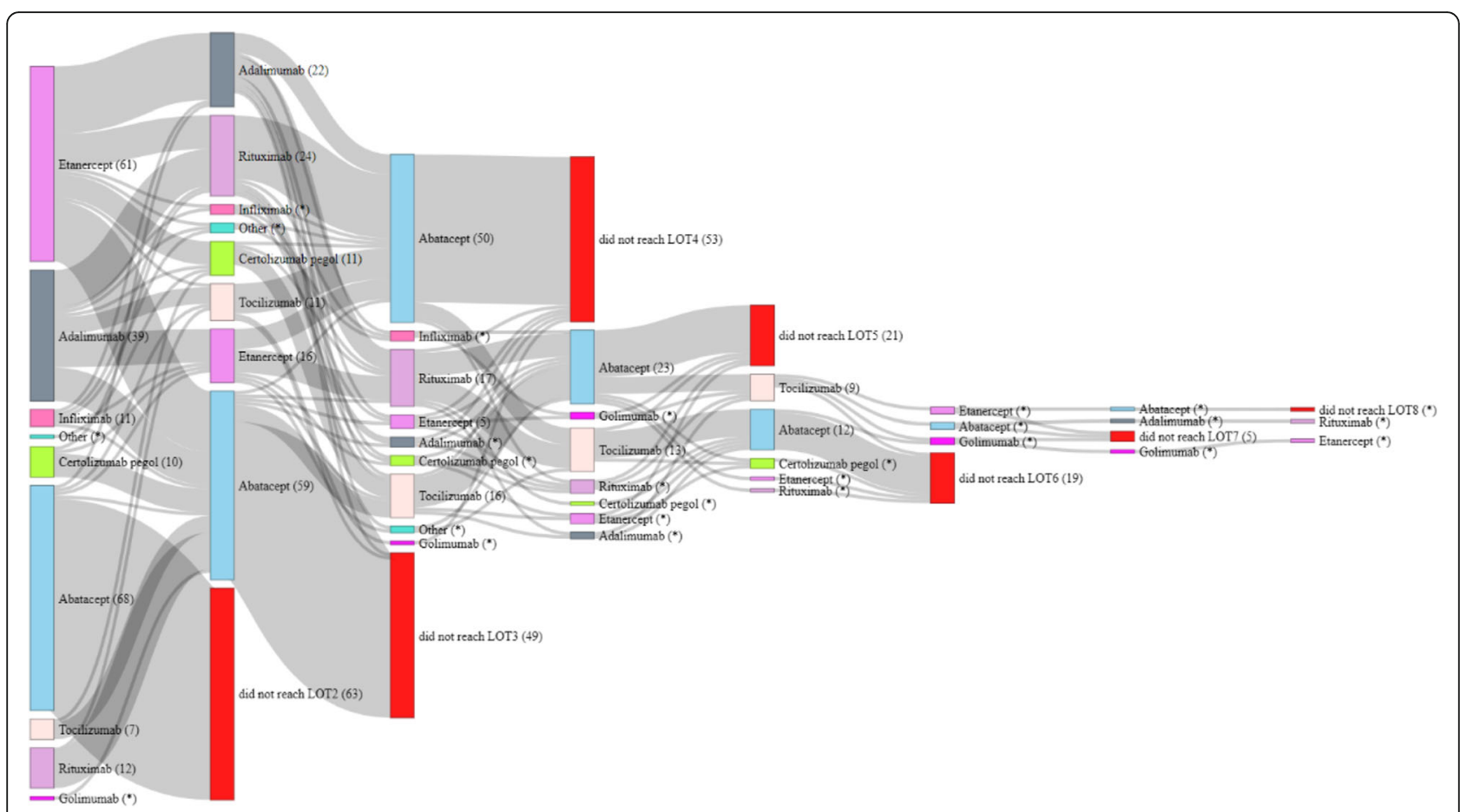

Fig. 1 Sankey diagram depicting treatment sequencing for bDMARDs in patients with rheumatoid arthritis. bDMARD: biologic disease modifying antirheumatic drug; LOT: line of therapy

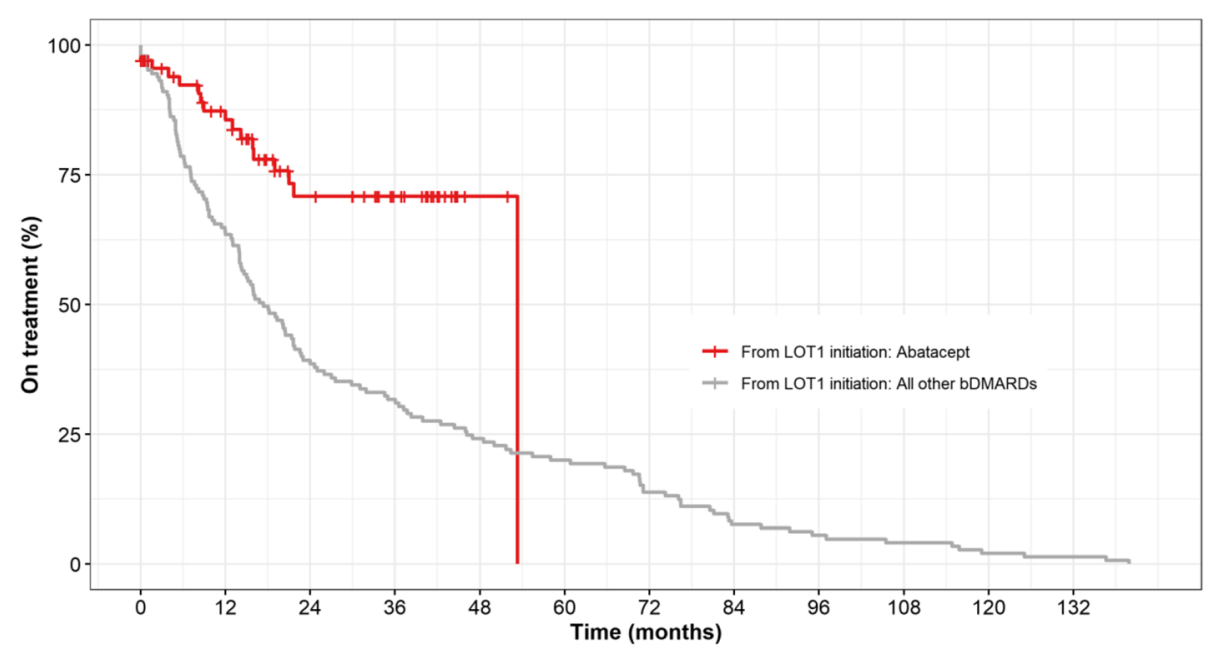

Number at risk
\begin{tabular}{|rrrrrrrrrrrrr|}
\hline 68 & 49 & 29 & 19 & $*$ & 0 & 0 & 0 & 0 & 0 & 0 & 0 \\
145 & 92 & 57 & 46 & 35 & 29 & 20 & 11 & 8 & 6 & $*$ & $*$ \\
\hline
\end{tabular}

Fig. 2 Time on treatment from LOT1 initiation stratified by abatacept vs other bDMARD therapy. Source: Henning et al. [25] 
Table 2 Time on treatment from LOT1 initiation, abatacept compared to other bDMARD therapy

\begin{tabular}{|c|c|c|c|c|c|c|c|}
\hline bDMARD therapy & Median (months) & R-Mean (months) & Max Follow Up (months) & Month 12 (\%) & Month 24 (\%) & Month 36 (\%) & $P$-value \\
\hline Abatacept & 53.4 & 41.2 & 53.4 & $85.6 \%$ & $70.9 \%$ & $70.9 \%$ & \multirow{2}{*}{$\begin{array}{l}W:<0.01^{*} \\
L R:<0.01^{*}\end{array}$} \\
\hline Other & 17.4 & 31.4 & 139.9 & $63.4 \%$ & $39.3 \%$ & $31.7 \%$ & \\
\hline
\end{tabular}

bDMARD Biologic disease-modifying antirheumatic drug, LOT Line of therapy, LR Log-Rank, R-Mean Restricted-mean (mean survival restricted at maximum followup within the cohort), $W$ Wilcoxon

* Denotes significance at $p$-value $<0.05$

experience infections requiring antibiotics, compared with patients who discontinued abatacept. However, this difference was not statistically significant, which may be due to the low number of recorded infections requiring antibiotics for patients receiving abatacept (Table 4).

Overall, treatment with abatacept or any other bDMARD was associated with reductions in DAS28-ESR and DAS28-CRP scores at 6 and 12 months after any LOT initiation, when adjusted for age and sex (Fig. 3, Tables 5 and 6). At 6 months, there was a greater incremental difference in DAS28-ESR scores between patients receiving abatacept versus other bDMARDs (observed for all ACPA and RF stratifications, with the exception of RF- and ACPA-/RF- subgroups). For DAS28-CRP, there was also a greater incremental difference in scores between patients receiving abatacept versus other bDMARDs (with the exception of RF- and ACPA+/RFsubgroups). Statistical significance was observed for the ACPA-/RF+ subgroup (LG mean: -2.22 ; 95\% CI: - 3.64,$0.81 ; p=0.01)$. At 12 months, similar trends were observed for DAS28-ESR and DAS28-CRP scores, with statistical significance observed for the overall cohort (LS mean: -0.56 ; 95\% CI: $-1.04,-0.07 ; p=0.03$ ) and the RF+ subgroup (LS mean: -0.49 ; 95\% CI: $-0.95,-0.03 ; p=$ $0.04)$, respectively.

The distribution of EULAR responses (good/moderate/no response) tended to be more favourable for patients receiving abatacept than when receiving other bDMARDs at any LOT $(22.8 \% / 41.3 \% / 35.9 \%$ versus $16.6 \% / 41.4 \% / 42.1 \%$ at 6 months, and $27.9 \% / 36.1 \% / 36.1 \%$ versus $21.2 \% / 34.5 \% / 44.2 \%$ at 12 months) (see Additional file 1: Table 1).

\section{Discussion}

This retrospective chart review study included data from 213 RA patients treated with abatacept at any LOT across four NHS centres in the UK from 2013 to 2017. The mean age of included patients was 55.2 years and patients were predominantly female (71.4\%). This aligns with the characteristics of the overall UK RA population, with more women affected by RA than men and diagnosis typically occurring between 40 and 60 years of age

Table 3 Distribution of patients who discontinued treatment - by LOT and time of discontinuation

\begin{tabular}{|c|c|c|c|c|c|}
\hline \multirow[t]{2}{*}{ LOT } & \multirow{2}{*}{$\begin{array}{l}\text { Received } \\
\text { treatment, } \\
\mathrm{n}\end{array}$} & \multirow{2}{*}{$\begin{array}{l}\text { Still on } \\
\text { treatment } \\
\text { at EOFU, } n \\
(\%)\end{array}$} & \multicolumn{3}{|l|}{ Discontinued treatment } \\
\hline & & & $\begin{array}{l}\text { Time to discontinuation, months } \\
\text { Mean (SD) }\end{array}$ & Within 6 months of LOT initiation & After 6 months of LOT initiation \\
\hline \multicolumn{6}{|c|}{ All patients $(n=213)$} \\
\hline LOT1 & 213 & $51(23.9 \%)$ & $29.4(31.8)$ & $36(16.9 \%)$ & $126(59.2 \%)$ \\
\hline LOT2 & 150 & $42(28.0 \%)$ & $20.2(20.4)$ & $29(19.3 \%)$ & 79 (52.7\%) \\
\hline LOT3 & 101 & $43(42.6 \%)$ & $16.7(16.2)$ & $20(19.8 \%)$ & $38(37.6 \%)$ \\
\hline LOT4 & 48 & $18(37.5 \%)$ & $22.2(25.1)$ & $11(22.9 \%)$ & 19 (39.6\%) \\
\hline \multicolumn{6}{|c|}{ Received abatacept } \\
\hline LOT1 & 68 & $51(75.0 \%)$ & $13.0(12.4)$ & $5(7.4 \%)$ & $12(17.6 \%)$ \\
\hline LOT2 & 59 & $40(67.8 \%)$ & $12.7(10.7)$ & $7(11.9 \%)$ & $12(20.3 \%)$ \\
\hline LOT3 & 50 & $38(76.0 \%)$ & $12.1(6.9)$ & $4(8.0 \%)$ & $8(16.0 \%)$ \\
\hline LOT4 & 23 & $11(47.8 \%)$ & $10.7(11.0)$ & $5(21.7 \%)$ & $7(30.4 \%)$ \\
\hline \multicolumn{6}{|c|}{ Received other bDMARD } \\
\hline LOT1 & 145 & $0(0.0 \%)$ & $31.4(32.8)$ & $31(21.4 \%)$ & $114(78.6 \%)$ \\
\hline LOT2 & 91 & $2(2.2 \%)$ & $21.8(21.6)$ & 22 (24.2\%) & 67 (73.6\%) \\
\hline LOT3 & 51 & 5 (9.8\%) & $17.9(17.7)$ & 16 (31.4\%) & 30 (58.8\%) \\
\hline LOT4 & 25 & 7 (28.0\%) & 29.9 (29.0) & 6 (24.0\%) & 12 (48.0\%) \\
\hline
\end{tabular}


Table 4 Infections requiring antibiotics for patients who discontinued treatment after 6 months of LOT initiation

\begin{tabular}{|c|c|c|c|c|c|c|c|c|}
\hline \multirow[t]{2}{*}{ Variable } & \multicolumn{2}{|c|}{ LOT1 $(n=126)$} & \multicolumn{2}{|c|}{ LOT2 $(n=79)$} & \multicolumn{2}{|c|}{ LOT3 $(n=38)$} & \multicolumn{2}{|c|}{ LOT4 $(n=19)$} \\
\hline & $\begin{array}{l}\text { Abatacept } \\
(n=12)\end{array}$ & $\begin{array}{l}\text { Other bDMARD } \\
(n=114)\end{array}$ & $\begin{array}{l}\text { Abatacept } \\
(n=12)\end{array}$ & $\begin{array}{l}\text { Other } \\
\text { bDMARD }(n= \\
67)\end{array}$ & $\begin{array}{l}\text { Abatacept } \\
(n=8)\end{array}$ & $\begin{array}{l}\text { Other } \\
\text { bDMARD }(n= \\
\text { 30) }\end{array}$ & $\begin{array}{l}\text { Abatacept } \\
(n=7)\end{array}$ & $\begin{array}{l}\text { Other } \\
\text { bDMARD }(n= \\
\text { 12) }\end{array}$ \\
\hline \multicolumn{9}{|c|}{ Infections (requiring antibiotics) } \\
\hline $\begin{array}{l}\text { Experienced } \\
\text { event (\%) }\end{array}$ & a & $27(23.7 \%)$ & a & $18(26.9 \%)$ & a & $13(43.3 \%)$ & a & $5(41.7 \%)$ \\
\hline $\begin{array}{l}\text { Discontinued } \\
\text { treatment (\%) }\end{array}$ & a & $27(23.7 \%)$ & a & $18(26.9 \%)$ & $0(0.0 \%)$ & $12(40.0 \%)$ & a & $5(41.7 \%)$ \\
\hline
\end{tabular}

LOT Line of therapy

${ }^{a}$ Cells suppressed due to small numbers

[7]. In this study, the median (IQR) duration of RA before starting bDMARD therapy was $3.9(2.1-8.5)$ years. Disease duration and number of prior DMARDs can affect treatment response in patients with established RA [26], and delayed start of disease-modifying therapy is associated with reduced disease control and poorer long-term outcomes $[27,28]$.

Of those patients with known ACPA and RF status ( $n$ $=115), 66.1 \%$ were $\mathrm{ACPA}+/ \mathrm{RF}+, 19.1 \%$ were $\mathrm{ACPA}$ -/RF-, 8.7\% were ACPA-/RF+, and 6.1\% were ACPA+/ RF-. However, there was a large proportion of patients with missing ACPA and RF data $(n=94 / 213$ and $n=$ $33 / 213$, respectively). This may be explained by the fact that ACPA was only introduced into the updated ACR/ EULAR Rheumatoid Arthritis Classification Criteria in 2010 [29] but the majority of patients in this study (70.4\%) were diagnosed with RA prior to 2009. It should also be noted that investigations of ACPA and RF are also recommended by NICE [30].

Changes in DAS28 scores observed in this study exceeded the 1.2- threshold considered to be clinically significant changes over time in patients with RA [31, 32]. In particular, RF negative status was associated with a trend towards lower incremental differences in DAS28 score when receiving abatacept. Published literature indicates that both RF and ACPA positivity are important

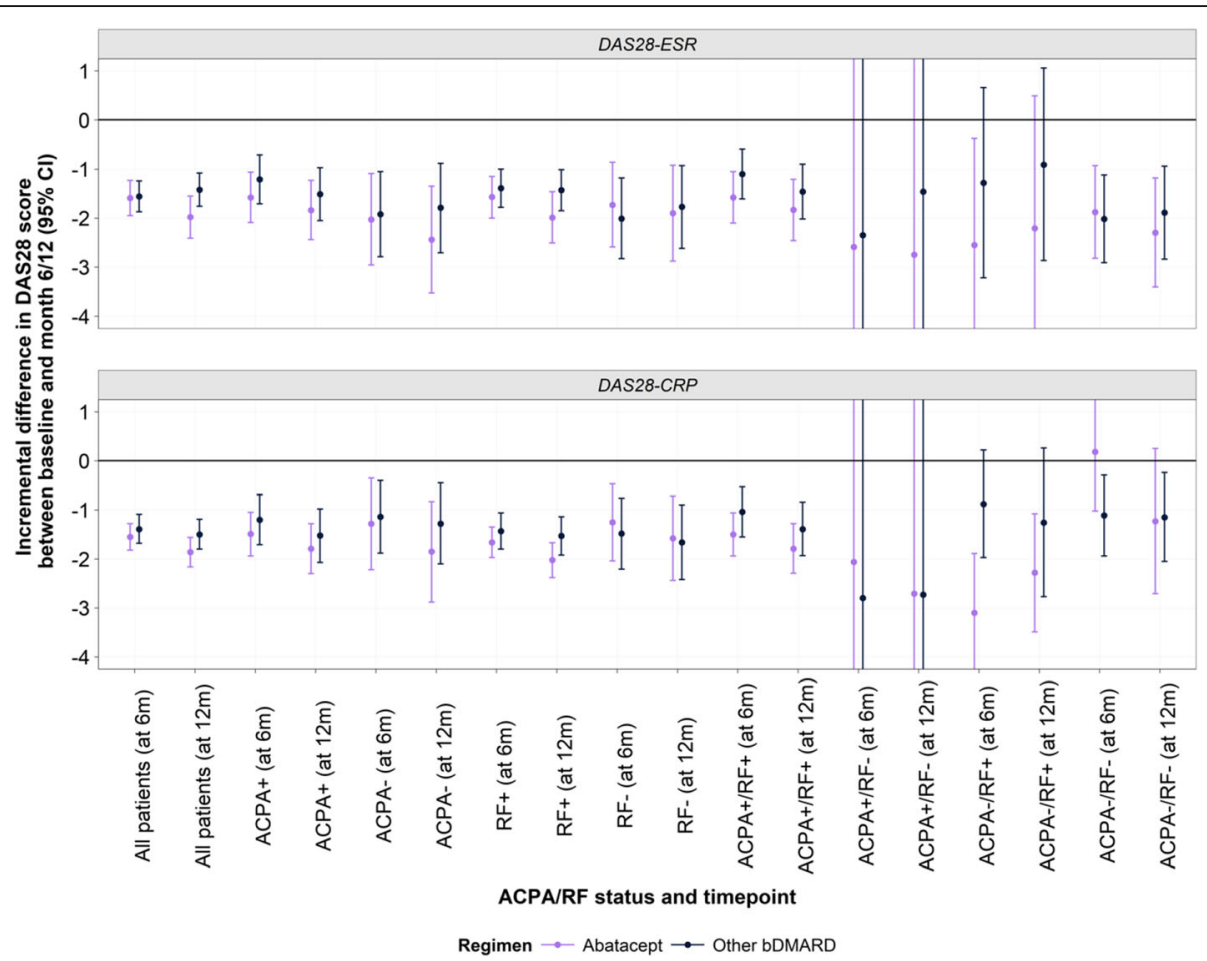

Fig. 3 Difference in DAS28-ESR and -CRP scores at 6 and 12 months after LOT initiation. ACPA: anti-citrullinated protein antibodies; bDMARD: biologic disease modifying antirheumatic drug; Cl: confidence interval; CRP: C-reactive protein; DAS: disease activity score; ESR: erythrocyte sedimentation rate; LOT: line of therapy; RF: rheumatoid factor. Note: Where applicable, error bars have been capped from -4 to 1 for presentability 
Table 5 Incremental change in DAS28-ESR and DAS28-CRP at 6 months after LOT initiation

\begin{tabular}{|c|c|c|c|c|c|c|c|c|c|}
\hline \multirow{3}{*}{$\begin{array}{l}\text { Antibody } \\
\text { Status }\end{array}$} & \multicolumn{9}{|c|}{ From 6 months } \\
\hline & \multicolumn{3}{|l|}{ Abatacept } & \multicolumn{3}{|c|}{ Other bDMARD } & \multicolumn{3}{|c|}{ Incremental difference } \\
\hline & Cohort (n) & Mean & $95 \% \mathrm{Cl}$ & Cohort (n) & Mean & $95 \% \mathrm{Cl}$ & LS Mean & $95 \% \mathrm{Cl}$ & $P$ value \\
\hline \multicolumn{10}{|l|}{ DAS28-ESR } \\
\hline All patients & 92 & -1.59 & $-1.95,-1.23$ & 145 & -1.56 & $-1.87,-1.24$ & -0.04 & $-0.45,0.38$ & 0.86 \\
\hline $\mathrm{ACPA}+$ & 48 & -1.58 & $-2.09,-1.06$ & 60 & -1.21 & $-1.71,-0.71$ & -0.37 & $-0.97,0.24$ & 0.24 \\
\hline ACPA- & 20 & -2.03 & $-2.96,-1.09$ & 30 & -1.92 & $-2.79,-1.05$ & -0.11 & $-0.94,0.73$ & 0.81 \\
\hline $\mathrm{RF}+$ & 65 & -1.57 & $-2.00,-1.15$ & 94 & -1.39 & $-1.78,-1.00$ & -0.19 & $-0.69,0.32$ & 0.47 \\
\hline RF- & 21 & -1.73 & $-2.59,-0.86$ & 34 & -2.01 & $-2.83,-1.18$ & 0.28 & $-0.51,1.08$ & 0.49 \\
\hline $\mathrm{ACPA}+/ \mathrm{RF}+$ & 45 & -1.58 & $-2.10,-1.05$ & 47 & -1.10 & $-1.61,-0.59$ & -0.48 & $-1.11,0.15$ & 0.14 \\
\hline $\mathrm{ACPA}+/ \mathrm{RF}-$ & a & -2.59 & $-36.06,30.88$ & a & -2.35 & $-54.75,50.05$ & -0.24 & $-5.27,4.79$ & 0.93 \\
\hline ACPA-/RF + & a & -2.55 & $-4.73,-0.37$ & 6 & -1.28 & $-3.22,0.66$ & -1.27 & $-3.14,0.60$ & 0.22 \\
\hline ACPA-/RF- & 16 & -1.88 & $-2.82,-0.93$ & 24 & -2.02 & $-2.91,-1.12$ & 0.14 & $-0.76,1.04$ & 0.76 \\
\hline \multicolumn{10}{|l|}{ DAS28-CRP } \\
\hline All patients & 116 & -1.55 & $-1.82,-1.28$ & 106 & -1.39 & $-1.68,-1.09$ & -0.16 & $-0.50,0.18$ & 0.36 \\
\hline $\mathrm{ACPA}+$ & 48 & -1.49 & $-1.94,-1.05$ & 42 & -1.20 & $-1.71,-0.69$ & -0.29 & $-0.83,0.24$ & 0.28 \\
\hline ACPA- & 11 & -1.28 & $-2.22,-0.35$ & 21 & -1.14 & $-1.88,-0.40$ & -0.14 & $-1.22,0.93$ & 0.80 \\
\hline $\mathrm{RF}+$ & 87 & -1.66 & $-1.97,-1.35$ & 69 & -1.43 & $-1.80,-1.06$ & -0.23 & $-0.64,0.18$ & 0.27 \\
\hline RF- & 17 & -1.25 & $-2.04,-0.47$ & 25 & -1.48 & $-2.21,-0.76$ & 0.23 & $-0.67,1.13$ & 0.62 \\
\hline $\mathrm{ACPA}+/ \mathrm{RF}+$ & 44 & -1.50 & $-1.94,-1.06$ & 38 & -1.04 & $-1.55,-0.53$ & -0.46 & $-1.02,0.11$ & 0.12 \\
\hline $\mathrm{ACPA}+/ \mathrm{RF}-$ & a & -2.06 & $-13.11,9.00$ & a & -2.80 & $-19.06,13.46$ & 0.74 & $-2.47,3.96$ & 0.69 \\
\hline ACPA-/RF + & a & -3.10 & $-4.32,-1.89$ & 6 & -0.88 & $-1.97,0.22$ & -2.22 & $-3.64,-0.81$ & 0.01 \\
\hline ACPA-/RF- & 6 & 0.18 & $-1.02,1.38$ & 15 & -1.11 & $-1.94,-0.29$ & 1.30 & $-0.08,2.67$ & 0.07 \\
\hline
\end{tabular}

bDMARD Biologic disease-modifying antirheumatic drugs, $C l$ Confidence interval, CRP c-reactive protein, DAS Disease activity score, ESR Erythrocyte sedimentation rate; $\mathrm{n}$ is the number of patients with a DAS score recorded at LOT initiation and at 6 months

${ }^{a}$ Cells suppressed due to small numbers

predictors of remission outcomes. For abatacept, ACPA positive status has been associated with better clinical response independent from disease activity $[33,34]$. The distribution of EULAR responses further supports the observation of greater improvement in DAS28-ESR scores in patients whilst receiving abatacept.

Patients receiving abatacept spent significantly longer on treatment than patients receiving other bDMARDs (median 53.4 months compared with 17.4 months from LOT1 initiation, respectively, $p<0.01)$. A similar pattern was observed at LOT2, with median time on treatment of 40.1 vs 17.1 months, respectively. This observation has also been reported in other studies where treatment persistence and durability were highest for abatacept initiators. In other real-world studies, abatacept retention was high, particularly when abatacept was used in earlier lines of treatment [24]. Use of abatacept has also been found to impact the overall pattern of ACPA fine specificities over time [35]. This longer duration of treatment adherence is both beneficial in terms of clinical effectiveness but also potentially for patients' quality of life and that of their family and carers $[8,9]$.
In both clinical trials and observational studies, abatacept was associated with a lower risk of hospitalised infection compared with other bDMARDs [36, 37]. Indeed, an observational study of abatacept compared with other bDMARDs reported a significant reduction in infections requiring hospitalisation in patients receiving abatacept (HR: 0.37 (95\% CI: 0.18-0.75) [38]. In the head-to-head Abatacept versus Adalimumab Comparison in Biologic-Naive RA Subjects with Background Methotrexate (AMPLE) phase 3b trial, serious infections were experienced in $12(3.8 \%)$ and $19(5.8 \%)$ patients, for abatacept versus adalimumab respectively; the majority of these infections resulted in hospitalisation (12 and 18) [39]. In this study, a greater proportion of patients receiving other bDMARDs in LOTs 1-4 experienced infection requiring antibiotics compared with those receiving abatacept when discontinuation was stratified by therapy (i.e. abatacept or other bDMARDs), specifically patients who have discontinued after 6 months from treatment initiation. These findings may indicate that treatment with abatacept is potentially associated with lower rates of infections given that there should be no difference in the recording of antibiotic use by type of 
Table 6 Incremental change in DAS28-ESR and DAS28-CRP at 12 months after LOT initiation

\begin{tabular}{|c|c|c|c|c|c|c|c|c|c|}
\hline \multirow{3}{*}{$\begin{array}{l}\text { Antibody } \\
\text { Status }\end{array}$} & \multicolumn{9}{|c|}{ From 12 months } \\
\hline & \multicolumn{3}{|l|}{ Abatacept } & \multicolumn{3}{|c|}{ Other bDMARD } & \multicolumn{3}{|c|}{ Incremental difference } \\
\hline & Cohort (n) & Mean & $95 \% \mathrm{Cl}$ & Cohort (n) & Mean & $95 \% \mathrm{Cl}$ & LS Mean & $95 \% \mathrm{Cl}$ & $P$ value \\
\hline \multicolumn{10}{|l|}{ DAS28-ESR } \\
\hline All patients & 61 & -1.98 & $-2.41,-1.55$ & 113 & -1.42 & $-1.76,-1.08$ & -0.56 & $-1.04,-0.07$ & 0.03 \\
\hline $\mathrm{ACPA}+$ & 33 & -1.84 & $-2.44,-1.23$ & 46 & -1.51 & $-2.05,-0.97$ & -0.33 & $-1.04,0.38$ & 0.37 \\
\hline ACPA- & 11 & -2.44 & $-3.53,-1.35$ & 24 & -1.79 & $-2.71,-0.88$ & -0.64 & $-1.70,0.41$ & 0.23 \\
\hline $\mathrm{RF}+$ & 42 & -1.99 & $-2.51,-1.46$ & 74 & -1.43 & $-1.85,-1.01$ & -0.56 & $-1.16,0.05$ & 0.07 \\
\hline RF- & 14 & -1.90 & $-2.88,-0.92$ & 28 & -1.77 & $-2.62,-0.93$ & -0.12 & $-1.04,0.79$ & 0.80 \\
\hline $\mathrm{ACPA}+/ \mathrm{RF}+$ & 31 & -1.83 & $-2.46,-1.21$ & 42 & -1.46 & $-2.02,-0.90$ & -0.37 & $-1.12,0.38$ & 0.33 \\
\hline $\mathrm{ACPA}+/ \mathrm{RF}-$ & a & -2.75 & $-28.19,22.70$ & a & -1.46 & $-59.19,56.28$ & -1.29 & $-6.91,4.33$ & 0.67 \\
\hline ACPA-/RF + & a & -2.21 & $-4.91,0.49$ & 6 & -0.91 & $-2.87,1.06$ & -1.30 & $-3.75,1.14$ & 0.32 \\
\hline ACPA-/RF- & 9 & -2.30 & $-3.41,-1.18$ & 18 & -1.89 & $-2.84,-0.94$ & -0.41 & $-1.55,0.74$ & 0.49 \\
\hline \multicolumn{10}{|l|}{ DAS28-CRP } \\
\hline All patients & 91 & -1.86 & $-2.16,-1.56$ & 90 & -1.50 & $-1.80,-1.19$ & -0.37 & $-0.75,0.01$ & 0.06 \\
\hline $\mathrm{ACPA}+$ & 35 & -1.79 & $-2.30,-1.28$ & 33 & -1.52 & $-2.07,-0.98$ & -0.26 & $-0.88,0.35$ & 0.40 \\
\hline ACPA- & 9 & -1.85 & $-2.88,-0.83$ & 16 & -1.28 & $-2.10,-0.45$ & -0.58 & $-1.79,0.64$ & 0.36 \\
\hline RF+ & 65 & -2.02 & $-2.38,-1.67$ & 57 & -1.53 & $-1.92,-1.14$ & -0.49 & $-0.95,-0.03$ & 0.04 \\
\hline RF- & 14 & -1.58 & $-2.44,-0.72$ & 21 & -1.66 & $-2.42,-0.90$ & 0.08 & $-0.90,1.07$ & 0.87 \\
\hline $\mathrm{ACPA}+/ \mathrm{RF}+$ & 33 & -1.79 & $-2.29,-1.28$ & 31 & -1.39 & $-1.93,-0.84$ & -0.40 & $-1.03,0.24$ & 0.22 \\
\hline $\mathrm{ACPA}+/ \mathrm{RF}-$ & a & -2.71 & $-13.76,8.35$ & a & -2.73 & $-15.73,10.28$ & 0.02 & $-3.62,3.66$ & 0.99 \\
\hline ACPA-/RF + & a & -2.28 & $-3.49,-1.08$ & a & -1.26 & $-2.77,0.26$ & -1.03 & $-2.60,0.55$ & 0.23 \\
\hline ACPA-/RF- & a & -1.23 & $-2.71,0.25$ & 12 & -1.15 & $-2.05,-0.24$ & -0.08 & $-1.74,1.57$ & 0.92 \\
\hline
\end{tabular}

GDMARD Biologic disease-modifying antirheumatic drugs, Cl Confidence interval, CRP c-reactive protein, DAS Disease activity score, ESR Erythrocyte sedimentation rate, $n$ Is the number of patients with a DAS score recorded at LOT initiation and at 12 months

${ }^{a}$ Cells suppressed due to small numbers

bDMARD therapy. Routine use of biologic therapies for RA that are associated with a lower risk of infections requiring antibiotics may benefit the implementation and success of national antimicrobial resistance (AMR) strategies; AMR is a complex and significant public health concern and existing national action plans aim to reduce the need for and use of antimicrobials [40]. However, the apparent association between infections requiring antibiotics and bDMARDS requires further investigation with larger study samples and more recent practice may account for data from the wider RA population.

There are several methodological limitations in this study. As the study was a retrospective chart review, it may have been subject to incomplete or inaccurate original data entry in the medical records, as well as similar issues during study data collection using the eCRF. A further limitation of this study is the extent of missing data (see Additional file 1: Tables 2 and 3). Whilst changes to clinical practice may account for some missing data (e.g. APCA status), incomplete eCRFs also restricted some subgroup analyses. The study was limited to four UK study centres with limited geographical spread, and thus the applicability of the findings to the wider UK population is unknown. The sample size for this study is also relatively modest, as abatacept has a relatively small secondary care market share across rheumatology specialities [41]. This is partly due to the specific clinical recommendations for use of abatacept in the UK $[42,43]$, as well as NHS England's commissioning framework which aims to initiate $90 \%$ of new patients on the best value biological medicine within 3 months of a biosimilar medicine being launched [44]. However, abatacept is considered to be cost-effective for patients with poor prognosis, with clear benefits in health-related quality of life [45]. In addition, there is a channelling bias associated with the study due to the preferential prescribing of abatacept, partly due to its favourable safety profile. The design of this study may have limited the analysis of treatment discontinuation and pathways. For example, in Fig. 3, discontinuation events whilst receiving abatacept were clustered within the first 24 months following treatment initiation, whereas discontinuation events were spread across the follow-up period whilst receiving other bDMARDs; this is also represented in Table 4. This suggests that if patients can tolerate abatacept in the short-term, their 
longer-term tolerability was also positive. However, as patients were only eligible for study inclusion if they received abatacept during the study period, any prior bDMARD therapies received in the lookback period would have had to be discontinued, by definition. This ultimately resulted in patients being more likely to reach EOFU when receiving abatacept. Finally, it should be noted that there was an unequal distribution of patients from each of the four centres due to their capacity; eligible patients were randomised by centre.

\section{Conclusions}

This study found clinical benefits associated with the use of abatacept, related to treatment persistence, durability and risk-benefit profile. These findings, along with the literature discussed, support recommendations in the NHS Long Term Plan to keep patient care close to or at home where possible [46]. At the time of writing, the COVID-19 pandemic is ongoing with unprecedented pressures across the entire health care system. The rheumatology community is working to optimise disease management strategies and transition to telehealth [47]. Early research suggests the risk of serious complications from COVID-19 is not increased for patients treated with bDMARDs or tsDMARDs [48]. However, preventative withdrawal of these treatments, which may occur at the time of COVID-19 symptom onset, should be avoided due to the increased risk of relapse and morbidity [48]. Future research should consider how abatacept and other bDMARDs are used in RA management during and after the pandemic.

\section{Supplementary Information}

The online version contains supplementary material available at https://doi. org/10.1186/s41927-020-00173-0.

Additional file 1: Table S1. EULAR response for abatacept vs other bDMARDs at 6 and 12 months after LOT initiation. Table S2. Summary of missingness for key baseline demographic and clinical variables at index. Table S3. DAS score change from LOT initiation missingness.

\begin{abstract}
Abbreviations
ACPA: Anti-citrullinated protein-peptide antibodies; ACR: American College of Rheumatology; AMR: Antimicrobial resistance; bDMARD: Biologic diseasemodifying antirheumatic drug; COVID-19: Coronavirus Disease 2019 [severe acute respiratory syndrome coronavirus 2 (SARS-CoV-2];

CSDMARD: Conventional synthetic disease-modifying antirheumatic drug; DAS28-CRP: Disease activity score for 28 joints - C-reactive protein; DAS28ESR: Disease activity score for 28 joints - erythrocyte sedimentation rate; eCRF: Electronic case report form; EOFU: End of follow-up; EULAR: European League Against Rheumatism; IQR: Interquartile range; LOT: Line of therapy; NICE: National Institute for Health and Care Excellence; NHS: National Health Service; RA: Rheumatoid arthritis; RF: Rheumatoid factor; TNFi: Tumour necrosis factor inhibitors; tsDMARD: Targeted synthetic disease-modifying antirheumatic drug; UK: United Kingdom
\end{abstract}

\section{Acknowledgements}

Study design review and critical review of publication were provided by Usman Farooqui of Bristol Myers Squibb. Critical review of publication and other editorial support were provided by Jeremiah O'Neill of Bristol Myers Squibb.

\section{Authors' contributions}

EC, SH, LG, DS, MH conceptualised and designed the study. MH was responsible for data analysis. All authors contributed to interpretation of the results, preparation and review of the manuscript, and approval of the final manuscript for publication.

\section{Funding}

This work was funded by Bristol Myers Squibb and supported by Health Economics and Outcomes Research Ltd. The funding agreement ensured the authors' independence in designing the study, interpreting the data, and preparing the manuscript for publication.

\section{Availability of data and materials}

The data that support the findings of this study are available from the study centres, but restrictions apply to the availability of these data, which were used under license for the current study and so are not publicly available. Data are however available from the authors upon reasonable request and with permission of the study centre(s).

\section{Ethics approval and consent to participate}

The study received ethical approval form the Yorkshire \& The Humber South Yorkshire Research Ethics Committee (Reference: 18/YH/0412) and research permissions from the Health Research Authority (Reference: 242712)

\section{Consent for publication}

Not applicable.

\section{Competing interests}

$\mathrm{SH}$ is an employee and shareholder of Bristol Myers Squibb. KP is an employee of Bristol Myers Squibb. LG, DS, MH, JH are employees of Health Economics and Outcomes Research Ltd., Cardiff, UK, who received fees from Bristol Myers Squibb in relation to this study. EC has received research grants from Bio-Cancer, Biogen, Novartis, Pfizer, Roche, Sanofi and UCB, consultancy from Abbvie, Amgen, Biogen, Biocon, Chugai Pharma, Eli Lilly, Gilead, Janssen, Merck Serono, Novartis, Pfizer, Regeneron, Roche, R-Pharm and Sanofi, speakers fee from Amgen, Bristol Myers Squibb, Chugai Pharma, Eli Lilly, Janssen, Novartis, Pfizer, Regeneron, Roche, Sanofi, and UCB. JRM has received consultancy fees from Abbvie, Eli Lilly, Pfizer and Bristol Myers Squibb and speaker fees from Pfizer, Bristol Myers Squibb and Novartis. SV and YP have no conflicts of interest to declare.

\section{Author details}

${ }^{1}$ CREATE Centre, Division of Infection and Immunity, Cardiff University School of Medicine, Wales, UK. ${ }^{2}$ Cardiff and Vale University Health Board, Cardiff, Wales, UK. ${ }^{3}$ Health Economics and Outcomes Research Ltd, Cardiff, UK. ${ }^{4}$ Cannock and Wolverhampton Rheumatology Centre, The Royal Wolverhampton NHS Trust, Wolverhampton, UK. ${ }^{5}$ Hull University Teaching Hospitals NHS Trust, Hull, UK. ${ }^{6}$ Sheffield Teaching Hospitals, Sheffield, UK. ${ }^{7}$ Bristol Myers Squibb, Uxbridge Business Park, Sanderson Road, Uxbridge, Middlesex, UK.

Received: 28 August 2020 Accepted: 22 December 2020

Published online: 04 February 2021

References

1. Smolen JS, Aletaha D, Mclnnes IB. Rheumatoid arthritis. Lancet. 2016; 388(10055):2023-38

2. Catrina Al, Svensson Cl, Malmstrom V, et al. Mechanisms leading from systemic autoimmunity to joint-specific disease in rheumatoid arthritis. Nat Rev Rheumatol. 2017;13(2):79-86.

3. Mosser DM, Edwards JP. Exploring the full spectrum of macrophage activation. Nat Rev Immunol. 2008;8(12):958-69.

4. Murphy KM, Weaver C. Janeway's immunobiology. 9th ed. New York: Garland Science; 2017.

5. Smolen JS, Aletaha D, Barton A, et al. Rheumatoid arthritis. Nat Rev Dis Primers. 2018:4:18001. 
6. Abhishek A, Doherty M, Kuo CF, et al. Rheumatoid arthritis is getting less frequent-results of a nationwide population-based cohort study. Rheumatology (Oxford). 2017;56(5):736-44.

7. National Rheumatoid Arthritis Society. What is RA? Available from: https:// www.nras.org.uk/what-is-ra-article. Accessed 25 Oct 2019.

8. Young A, Dixey J, Cox $\mathrm{N}$, et al. How does functional disability in early rheumatoid arthritis (RA) affect patients and their lives? Results of 5 years of follow-up in 732 patients from the Early RA Study (ERAS). Rheumatology (Oxford). 2000;39(6):603-11.

9. Matcham F, Scott IC, Rayner L, et al. The impact of rheumatoid arthritis on quality-of-life assessed using the SF-36: a systematic review and metaanalysis. Semin Arthritis Rheum. 2014;44(2):123-30.

10. Smolen JS, Landewé RBM, Bijlsma JWJ, et al. EULAR recommendations for the management of rheumatoid arthritis with synthetic and biological disease-modifying antirheumatic drugs: 2019 update. Ann Rheum Dis. 2020. https://doi.org/10.1136/annrheumdis-2019-216655.

11. Singh JA, Saag KG, Bridges SL Jr, et al. 2015 American College of Rheumatology guideline for the treatment of rheumatoid arthritis. Arthritis Rheumatol. 2016;68(1):1-26.

12. National Institute for Health and Care Excellence. Drug treatment for rheumatoid arthritis. 2018. Available from: https://pathways.nice.org.uk/ pathways/rheumatoid-arthritis\#path=view\%3A/pathways/rheumatoidarthritis/drug-treatment-for-rheumatoid-arthritis.xml. Accessed 23 Jan 2018.

13. Daha NA, Toes RE. Rheumatoid arthritis: are ACPA-positive and ACPAnegative RA the same disease? Nat Rev Rheumatol. 2011;7(4):202-3.

14. Jilani AA, Mackworth-Young CG. The role of citrullinated protein antibodies in predicting erosive disease in rheumatoid arthritis: a systematic literature review and meta-analysis. Int J Rheumatol. 2015;2015:728610.

15. Ohmura K, Terao C, Maruya E, et al. Anti-citrullinated peptide antibodynegative RA is a genetically distinct subset: a definitive study using only bone-erosive ACPA-negative rheumatoid arthritis. Rheumatology (Oxford, England). 2010;49(12):2298-304.

16. Santos-Moreno P, Sánchez G, Castro C. Rheumatoid factor as predictor of response to treatment with anti-TNF alpha drugs in patients with rheumatoid arthritis: results of a cohort study. Medicine. 2019;98(5):e14181.

17. Sellam J, Hendel-Chavez $\mathrm{H}$, Rouanet $\mathrm{S}$, et al. B cell activation biomarkers as predictive factors for the response to rituximab in rheumatoid arthritis: a sixmonth, national, multicenter, open-label study. Arthritis Rheum. 2011;63(4): 933-8.

18. Syversen SW, Gaarder PI, Goll GL, et al. High anti-cyclic citrullinated peptide levels and an algorithm of four variables predict radiographic progression in patients with rheumatoid arthritis: results from a 10-year longitudinal study. Ann Rheum Dis. 2008;67(2):212-7.

19. Cagnotto G, Willim M, Nilsson J-Å, et al. Abatacept in rheumatoid arthritis: survival on drug, clinical outcomes, and their predictors - data from a large national quality register. Arthritis Res Ther. 2020;22(1):15.

20. Nüßlein HG, Alten R, Galeazzi M, et al. Prognostic factors for abatacept retention in patients who received at least one prior biologic agent: an interim analysis from the observational, prospective ACTION study. BMC Musculoskelet Disord. 2015;16(1):176.

21. Peichl P, Alten R, Galeazzi M, et al. Abatacept retention and clinical outcomes in Austrian patients with rheumatoid arthritis: real-world data from the 2-year ACTION study. Wien Med Wochenschr. 2020;170(5):132-40.

22. Pope JE, Rampakakis E, Sampalis J. The durability of abatacept as a first and subsequent biologic and improvement in HAQ from a large multi-site realworld study. Semin Arthritis Rheum. 2015;44(5):499-505.

23. Choquette D, Bessette L, Alemao E, et al. Persistence rates of abatacept and TNF inhibitors used as first or second biologic DMARDs in the treatment of rheumatoid arthritis: 9 years of experience from the Rhumadata ${ }^{\circledR}$ clinical database and registry. Arthritis Res Ther. 2019;21(1):138.

24. Park J-A, Lee M-Y, Nam JH, et al. Real-world treatment persistence of nontumor necrosis factor inhibitors versus tumor necrosis factor inhibitors among patients with rheumatoid arthritis in South Korea. Curr Med Res Opin. 2020;36(2):343-51.

25. Henning S, Groves L, Hurst M, et al. AB0295 change in disease activity and treatment response after abatacept treatment for rheumatoid arthritis: realworld evidence from the UK. Ann Rheum Dis. 2020;79(1):1446-7.

26. Aletaha D, Maa J-f, Chen S, et al. Effect of disease duration and prior disease-modifying antirheumatic drug use on treatment outcomes in patients with rheumatoid arthritis. Ann Rheum Dis. 2019;78(12):1609.
27. Molina E, del Rincon I, Restrepo JF, et al. Association of socioeconomic status with treatment delays, disease activity, joint damage, and disability in rheumatoid arthritis. Arthritis Care Res. 2015;67(7):940-6.

28. van der Heide A, Jacobs JW, Bijlsma JW, et al. The effectiveness of early treatment with "second-line" antirheumatic drugs. A randomized, controlled trial. Ann Intern Med. 1996;124(8):699-707.

29. Kay J, Jupchurch KS. ACR/EULAR 2010 rheumatoid arthritis classification criteria. Rheumatology. 2012;51(suppl_6):vi5-9.

30. National Institute for Health and Care Excellence. Rheumatoid arthritis in adults: management. 2018. Available from: https://www.nice.org.uk/ guidance/ng100/resources/rheumatoid-arthritis-in-adults-managementpdf-66141531233989.

31. Ward MM, Guthrie LC, Alba MI. Clinically important changes in individual and composite measures of rheumatoid arthritis activity: thresholds applicable in clinical trials. Ann Rheum Dis. 2015;74(9):1691-6.

32. National Institute for Health and Care Excellence. Adalimumab, etanercept, infliximab, certolizumab pegol, golimumab, tocilizumab and abatacept for rheumatoid arthritis not previously treated with DMARDs or after conventional DMARDs only have failed. 2016. Available from: https://www. nice.org.uk/guidance/ta375. Accessed 7 May 2020.

33. Sokolove J, Schiff $M$, Fleischmann $R$, et al. Impact of baseline anti-cyclic citrullinated peptide-2 antibody concentration on efficacy outcomes following treatment with subcutaneous abatacept or adalimumab: 2-year results from the AMPLE trial. Ann Rheum Dis. 2016;75(4):709-14.

34. Gottenberg JE, Ravaud P, Cantagrel A, et al. Positivity for anti-cyclic citrullinated peptide is associated with a better response to abatacept: data from the 'Orencia and Rheumatoid Arthritis' registry. Ann Rheum Dis. 2012; 71(11):1815-9.

35. Connolly S, Maldonado M, Schiff M, et al. FRI0039 modulation of the ACPA fine specificity in patients with RA treated with either abatacept or adalimumab in the AMPLE study. Ann Rheum Dis. 2014;73(Suppl 2):395.

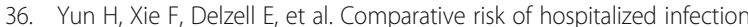
associated with biologic agents in rheumatoid arthritis patients enrolled in Medicare. Arthritis Rheumatol. 2016;68(1):56-66.

37. Paul D, Lobo F, Patel V, et al. FRI0113 comparison of infection-related hospitalization costs in patients with rheumatoid arthritis (RA) treated with ABATACEPT or other targeted disease-modifying anti-rheumatic drugs (TDMARDS). Ann Rheum Dis. 2019;78(Suppl 2):724.

38. Ozen G, Pedro S, Schumacher R, et al. Safety of abatacept compared with other biologic and conventional synthetic disease-modifying antirheumatic drugs in patients with rheumatoid arthritis: data from an observational study. Arthritis Res Ther. 2019;21(1):141.

39. Schiff $M$, Weinblatt ME, Valente $R$, et al. Head-to-head comparison of subcutaneous abatacept versus adalimumab for rheumatoid arthritis: twoyear efficacy and safety findings from AMPLE trial. Ann Rheum Dis. 2014; 73(1):86-94.

40. HM Government. Tackling antimicrobial resistance 2019-2024 - the UK's five-year national action plan. 2019. Available from: https://assets.publishing. service.gov.uk/government/uploads/system/uploads/attachment_data/file/ 784894/UK_AMR_5_year_national_action_plan.pdf. Accessed 1 May 2020.

41. Aladul MI, Fitzpatrick RW, Chapman SR. The effect of new biosimilars in rheumatology and gastroenterology specialities on UK healthcare budgets: results of a budget impact analysis. Res Soc Adm Pharm. 2019:15(3):310-7.

42. National Institute for Health and Care Excellence. Adalimumab, etanercept, infliximab, certolizumab pegol, golimumab, tocilizumab and abatacept for rheumatoid arthritis not previously treated with DMARDs or after conventional DMARDs only have failed; technology appraisal guidance [TA375]. 2016. Available from: https://www.nice.org.uk/guidance/ta375. Accessed 19 Oct 2020

43. National Institute for Health and Care Excellence. Adalimumab, etanercept, infliximab, rituximab and abatacept for the treatment of rheumatoid arthritis after the failure of a TNF inhibitor; technology appraisal guidance [TA195]. 2010. Available from: https://www.nice.org.uk/guidance/ta195. Accessed 19 Oct 2020

44. NHS England. Commissioning framework for biological medicines (including biosimilar medicines). 2017. Available from: https://www.england.nhs.uk/wpcontent/uploads/2017/09/biosimilar-medicines-commissioning-framework. pdf. Accessed 21 Oct 2020.

45. Alemao E, Johal S, Al MJ, et al. Cost-effectiveness analysis of abatacept compared with adalimumab on background methotrexate in biologic-naive 
adult patients with rheumatoid arthritis and poor prognosis. Value Health. 2018;21(2):193-202.

46. National Health Service. The NHS long term plan. 2019. Available from: https://www.longtermplan.nhs.uk/wp-content/uploads/2019/08/nhs-longterm-plan-version-1.2.pdf. Accessed 6 May 2020.

47. Lewandowski LB, Hsieh E. Global rheumatology in the time of COVID-19. Lancet Rheumatol. 2020;2(5):e254-e5.

48. Monti S, Balduzzi S, Delvino P, et al. Clinical course of COVID-19 in a series of patients with chronic arthritis treated with immunosuppressive targeted therapies. Ann Rheum Dis. 2020;79(5):667.

\section{Publisher's Note}

Springer Nature remains neutral with regard to jurisdictional claims in published maps and institutional affiliations.

Ready to submit your research? Choose BMC and benefit from:

- fast, convenient online submission

- thorough peer review by experienced researchers in your field

- rapid publication on acceptance

- support for research data, including large and complex data types

- gold Open Access which fosters wider collaboration and increased citations

- maximum visibility for your research: over $100 \mathrm{M}$ website views per year

At BMC, research is always in progress.

Learn more biomedcentral.com/submissions 